\title{
A two-sided approach to estimate heat transfer processes within the active layer of the Murtèl-Corvatsch rock glacier
}

\author{
M. Scherler ${ }^{1, *}$, S. Schneider ${ }^{1}$, M. Hoelzle ${ }^{1}$, and C. Hauck ${ }^{1}$ \\ ${ }^{1}$ Departement of Geosciences, University of Fribourg, Chemin du Musée 4, 1700 Fribourg, Switzerland \\ *now at: Swiss Federal Research Institute WSL, Zürcherstrasse 111, 8903 Birmensdorf, Switzerland \\ Correspondence to: M. Scherler (martin.scherler@wsl.ch)
}

Received: 7 June 2013 - Published in Earth Surf. Dynam. Discuss.: 2 July 2013

Revised: 28 January 2014 - Accepted: 7 February 2014 - Published: 5 March 2014

\begin{abstract}
The thermal regime of permafrost on scree slopes and rock glaciers is characterized by the importance of air flow driven convective and advective heat transfer processes. These processes are supposed to be part of the energy balance in the active layer of rock glaciers leading to lower subsurface temperatures than would be expected at the lower limit of discontinuous high mountain permafrost. In this study, new parametrizations were introduced in a numerical soil model (the Coup Model) to simulate permafrost temperatures observed in a borehole at the Murtèl rock glacier in the Swiss Alps in the period from 1997 to 2008. A soil heat sink and source layer was implemented within the active layer, which was parametrized experimentally to account for and quantify the contribution of air flow driven heat transfer on the measured permafrost temperatures. The experimental model calibration process yielded a value of about $28.9 \mathrm{Wm}^{-2}$ for the heat sink during the period from mid September to mid January and one of $26 \mathrm{Wm}^{-2}$ for the heat source in the period from June to mid September. Energy balance measurements, integrated over a $3.5 \mathrm{~m}$-thick blocky surface layer, showed seasonal deviations between a zero energy balance and the calculated sum of the energy balance components of around $5.5 \mathrm{Wm}^{-2}$ in fall/winter, $-0.9 \mathrm{Wm}^{-2}$ in winter/spring and around $-9.4 \mathrm{Wm}^{-2}$ in summer. The calculations integrate heat exchange processes including thermal radiation between adjacent blocks, turbulent heat flux and energy storage change in the blocky surface layer. Finally, it is hypothesized that these deviations approximately equal unmeasured freezing and thawing processes within the blocky surface layer.
\end{abstract}

\section{Introduction}

Permafrost in high mountain environments is a common phenomenon at altitudes above $2400 \mathrm{~m}$ a.s.l in the European Alps. It can be found in areas with various subsurface characteristics such as solid rock, weathered rock with a fine grained surface cover, or talus slopes consisting of coarse debris. At debris-covered sites in high mountains relatively cold permafrost can be found at lower altitudes than would be expected from the prevailing mean annual air temperatures. One explanation for this are the thermal properties of blocky surfaces, which may lead to the existence of permafrost at sites where without such ground characteristics permafrost would not develop (e.g., Harris and Pedersen, 1998; Delaloye and Lambiel, 2005; Hanson and Hoelzle, 2004). One special permafrost form in talus slopes are rock glaciers. This type of permafrost is characterized by ice-supersaturated sediments covered by large blocks (Arenson et al., 2002). Rock glaciers often show lobes of tens of meters in wavelength and a few meters in amplitude at the surface (Kääb et al., 1998). Besides the subsurface material, the ice and water content of the ground, the energy balance at the surface is the most important factor for the existence of permafrost. Due to the coarse surface layer of a rock glacier with boulders of up to $10 \mathrm{~m}$ in diameter the determination of an energy balance at the surface is a complex problem. The surface in this case is rather to be seen as a blocky surface layer of several meters in thickness comprising a large part of the blocky surface layer with 
voids and the air column above (Herz et al., 2003). In surface energy balance measurements even under less complicated circumstances, e.g., arctic plains with sparse vegetation, there are usually deviation terms of up to $20 \mathrm{Wm}^{-2}$ to a zero energy balance reported due to method-related errors and parametrizations (Westermann et al., 2009). A study by Mittaz et al. (2000) at the Murtèl rock glacier found deviations from a zero energy balance of up to $78 \mathrm{Wm}^{-2}$ in winter and $-130 \mathrm{Wm}^{-2}$ in summer, which were explained by advective heat transfer processes through voids within the debris.

Several processes of advective and convective air circulation in blocky material have been described in the literature. A convective process is the Balch effect (Balch, 1900), which describes the replacement of warm air with cold air within the voids of the blocky material due to density differences. An additional convective/advective process on inclined blocky slopes called the chimney effect was first described in a study by Wakonigg (1996). In winter relatively warm air within the blocky layer ascends beneath the snow cover, creating melting holes in the upper part of the slope, which facilitates the aspiration of cold air inside the talus slope (Delaloye et al., 2003). Discharge of cold air in summer driven by gravity may lead to advective heat transfer by air circulation (Delaloye et al., 2003). Further studies stressing the importance of air circulation within the active layer of coarse blocky scree slopes for the Alps have been presented by, e.g., Vonder Mühll et al. (2003). Tanaka et al. (2000) describe these effects in a modeling study for mountainous regions in Korea and Japan. Similar effects are also described for anthropogenic structures, i.e., crushed rock highway embankments (e.g., Binxiang et al., 2007). Harris and Pedersen (1998) suggested an advective process that is characterized by continuous air exchange between the voids and the atmosphere. Air exchange with the atmosphere will result in almost instantaneous warming and cooling of the blocky debris to a considerable depth in response to changes in air temperature. Heat transfer by water flow from precipitation between the blocks is expected to lead to a reduction in the temperature gradients and in the blocky surface layer, which will be reflected in the thermal conduction term and the storage change (integrated over the entire surface layer).

In model studies aiming at the simulation of the hydrothermal regime and the response of permafrost to climate change, three-dimensional energy exchange processes in the active layer are often approximated by very low effective thermal conductivities of the coarse blocky material, i.e., the surface layer is treated as a "thermal semi-conductor" (see, e.g., Cheng et al., 2007 or Gruber and Hoelzle, 2008).

The aim of this study was to compare the energy balance of a calibrated one-dimensional heat and mass transfer model, which was used in an earlier study to simulate the thermal regime of the Murtèl rock glacier under the influence of climate change scenarios (see Scherler et al., 2013), to a measured energy balance.
This approach has been chosen as existing energy balance formulations do not account for the complex surface of block materials, which is addressed here by developing a volumetric energy balance. Because existing models, such as the Coup Model used in this study, do not account for all the energy exchange processes within such surface materials, a method to account for these by adding a sink/source component is examined here. The results of both methods and the relative strengths/weaknesses of the approaches with respect to different applications are discussed.

This approach also allowed for the indirect quantification of the total energy exchange by three-dimensional heat transfer processes. In the measured energy balance the use of additional terms for radiative heat transfer between the blocks (see, e.g., Kunii and Smith, 1960; Fillion et al., 2011), heat storage change and turbulent heat flux in the blocky surface layer allowed for the approximation of seasonal freezing and thawing processes within the active layer and the permafrost.

\subsection{Coup Model}

The model used in this study is a one-dimensional heat and mass transfer model for the soil-snow-atmosphere system (Coup Model; Jansson and Karlberg, 2011). The model was chosen for a sensitivity study involving transient hydrothermal simulations using RCM derived climate scenarios of the 21st century (see Scherler et al., 2013). The empirical parametrization used in the calibration of the model, as described below, was a part of this project. In this study, a detailed comparison of the simulated and the measured energy balance is presented.

Two coupled partial differential equations for water and heat flow are the core of the Coup Model. These equations are solved with an explicit forward difference method. A detailed description of the model including all its equations and parameters is given in Jansson and Karlberg (2011). Applications of the model are detailed in a number of studies (e.g., Johnsson and Lundin, 1991; Stähli et al., 1996; Bayard et al., 2005; Scherler et al., 2010, 2013). Processes that are important for permafrost, such as freezing and thawing of the soil (Lundin, 1990) as well as the accumulation, metamorphosis, and melt of a snow cover (Gustafsson et al., 2001), are included in the model. The model is driven by hourly averages of air temperature, relative humidity, wind speed, global radiation, incoming longwave radiation and precipitation. The number of iterations per day used in the simulation is 1440 . The upper boundary condition is given by a surface energy balance at the soil-snow-atmosphere boundary layer. The lower boundary condition at the bottom of the soil column at a depth of $70 \mathrm{~m}$ is given as a zero heat flux and a seepage flow of percolating water. The model is initialized with an ice content of $85 \%$ in the permafrost at depths of 3.4 to $22.4 \mathrm{~m}$ below the surface and a starting temperature of $-1.5^{\circ} \mathrm{C}$.

To account for three-dimensional heat transfer by longwave radiation and air circulation between the blocks, which 

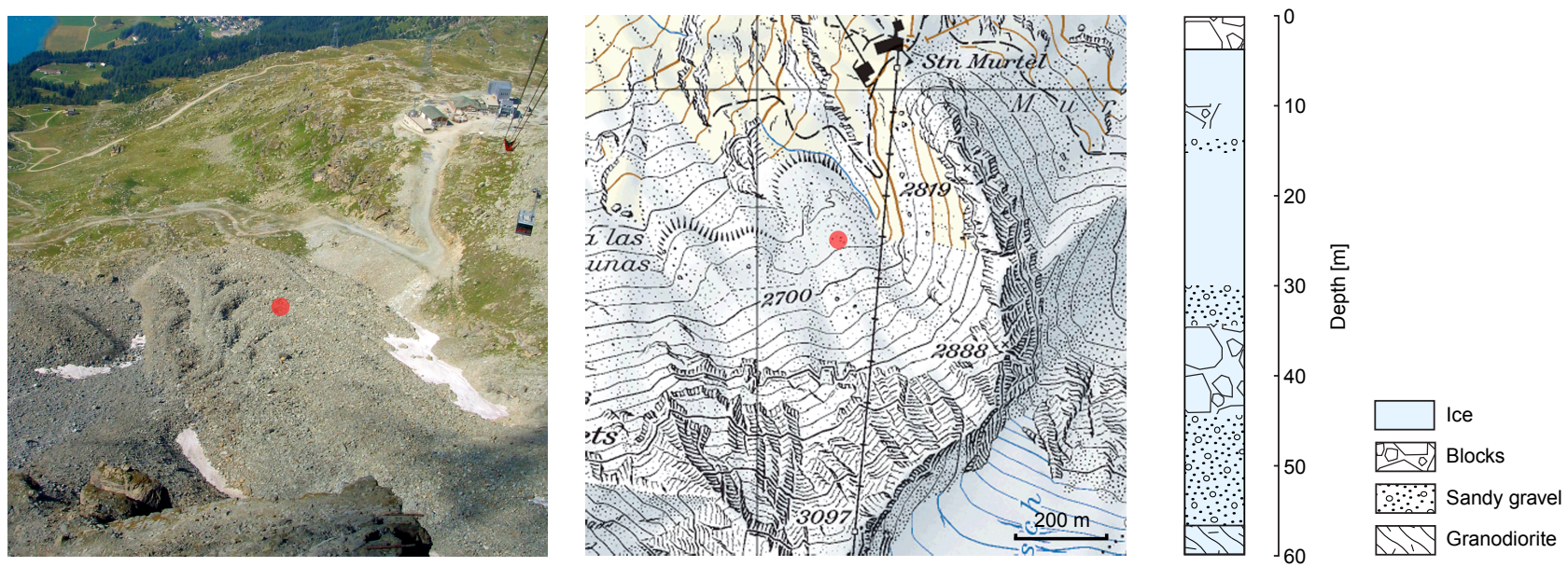

Figure 1. Field site photograph, situation map (reproduced by permission of swisstopo (BA14029)), and approximative stratigraphy (according to Arenson et al., 2002) indicating the depth of the permafrost table. The red dot shows the location of the borehole and the meteorological station.

cannot be simulated directly in a one-dimensional model, but are supposed to have a significant impact on the thermal regime of the active layer in coarse debris-covered permafrost (Delaloye and Lambiel, 2005; Mittaz et al., 2000; Hanson and Hoelzle, 2004), a layer that serves as a heat source/sink is introduced in the model. It adds energy to the soil system in the summer season (June-mid September) and extracts energy in winter (mid September-mid January). The layer is $1 \mathrm{~m}$ thick and is situated between 0.2 and $1.2 \mathrm{~m}$ depth. The thickness is chosen large enough to approximate the natural situation (i.e., $40 \%$ porosity in the active layer) and thin enough not to cause numerical problems. This energy source/sink layer is parametrized based partly on knowledge taken from an observational study done by Mittaz et al. (2000), who found significant deviations to a zero energy balance in summer and winter in measurements at the Murtèl rock glacier site. The values for the parametrization were then adjusted experimentally during the calibration phase of the model. Heat source and heat sink are treated as constant in the respective seasons due to simplicity. Parametrization is considered as successful when measured borehole temperatures and simulated temperatures at two depths within the permafrost show the best fit. To reach near thermodynamic equilibrium conditions the model was run for four 11-year cycles in the case with a heat source and sink parametrization and for eleven 11-year cycles in the case without a heat pump. This discrepancy is due to the $85 \%$ ice content in the respective layers (5.5 and $10.5 \mathrm{~m}$ ), which has to be melted in the case of no additional heat sink/source in the model before reaching an approximate thermodynamic equilibrium.

\section{Site description}

The site of this study is the Murtèl-Corvatsch rock glacier in the Upper Engadine, Switzerland (see Fig. 1). The rock glacier reaches from 2850 to $2620 \mathrm{~m}$ a.s.l. and is $400 \mathrm{~m}$ long and $200 \mathrm{~m}$ wide, facing north-northwest. At the site a $60 \mathrm{~m}$ deep borehole was drilled and equipped with thermistors in 1987 that have been manually logged in 1-month intervals until 1992, and since then data has been stored automatically by a logger collecting temperature data in $6 \mathrm{~h}$ intervals (Hoelzle et al., 2002). A micrometeorological station established in 1997 at $2700 \mathrm{~m}$ a.s.l. next to the borehole measures short-wave and long-wave incoming and outgoing radiation, air temperature, surface temperature, relative humidity, wind speed and direction (Mittaz et al., 2000; Hoelzle and Gruber, 2008). The site is characterized by a coarse blocky surface layer of approximately $3-3.5 \mathrm{~m}$ in thickness above a massive ice core down to $28 \mathrm{~m}$ and a frozen blocky layer underneath, reaching from 28 to $50 \mathrm{~m}$ probably adjacent to the bedrock (Arenson et al., 2002). The ice core has a temperature of $-2{ }^{\circ} \mathrm{C}$ at $10 \mathrm{~m}$ depth and $-1.4^{\circ} \mathrm{C}$ at $25 \mathrm{~m}$ depth. The active layer has a thickness of $3.2 \mathrm{~m}$ on average. The diameters of the boulders forming the surface layer are in the range of decimeters up to several meters. The comparison of the stratigraphy of the studied borehole with the stratigraphies of two boreholes located within a distance of $30 \mathrm{~m}$ shows significant small-scale heterogeneities in the rock glacier (Vonder Mühll et al., 2001; Arenson et al., 2010). In direct proximity of the rock glacier, areas with fine grained subsurface material/soil as well as solid rock exist that show no permafrost conditions (Schneider et al., 2012). The rocks at the site mainly consist of metamorphic granodiorite and basalt (Schneider et al., 2012). Annual precipitation at the site is about $900 \mathrm{~mm}(982 \mathrm{~mm}$ St Moritz 1951-1980; $856 \mathrm{~mm}$ Piz Corvatsch 1984-1997). Typical maximum snow cover 
Table 1. Meteorological station equipment and accuracy.

\begin{tabular}{|c|c|c|c|}
\hline Variable & Sensor & Sensor type & Accuracy \\
\hline & Logger (Campbell) & $\begin{array}{l}\text { CR10X data logger; } \\
\text { SDM-INT8 interval timer; } \\
\text { AM416 multiplexer }\end{array}$ & \\
\hline $\begin{array}{l}\text { Radiation (short- and } \\
\text { longwave) }\end{array}$ & $\begin{array}{l}\text { CNR1 net radiometer } \\
\text { (Kipp \& Zonen) }\end{array}$ & $\begin{array}{l}2 \text { pyranometer CM3; } \\
2 \text { pyrgeometer CG3; } \\
\text { Pt-100 temp. sensor }\end{array}$ & $\begin{array}{l} \pm 10 \% \\
\pm 2 \mathrm{~K}\end{array}$ \\
\hline $\begin{array}{l}\text { Air temperature/ } \\
\text { humidity }\end{array}$ & $\begin{array}{l}\text { MP-100A } \\
\text { ventilated } \\
\text { (Rotronic) }\end{array}$ & $\begin{array}{l}\text { RTD Pt-100; } \\
\text { C94 hygrometers }\end{array}$ & $\pm 10 \%$ \\
\hline Wind speed & 05103-5 model (Young) & Potentiometer & $\pm 0.3 \mathrm{~m} \mathrm{~s}^{-1}$ \\
\hline Snow height & SR50 (Campbell) & $\begin{array}{l}\text { Ultrasonic electrostatic } \\
\text { transducer }\end{array}$ & $\pm 0.01 \mathrm{~m}$ \\
\hline $\begin{array}{l}\text { Surface } \\
\text { temperature }\end{array}$ & Infrared thermometer & Irt/c.5 & $\pm 1.5^{\circ} \mathrm{C}$ \\
\hline $\begin{array}{l}\text { Borehole } \\
\text { temperatures }\end{array}$ & $\begin{array}{l}\text { YSI } 44006 \text { (Yellow } \\
\text { Springs Instruments) }\end{array}$ & NTC thermistors & $\pm 0.02^{\circ} \mathrm{C}$ \\
\hline Precipitation & $\begin{array}{l}\text { MeteoSwiss } \\
\text { (Corvatsch summit) }\end{array}$ & Rain gauge & $\pm 30 \%$ \\
\hline
\end{tabular}

thickness is between $1 \mathrm{~m}$ and $2 \mathrm{~m}$. Mean annual air temperature is $-1.7^{\circ} \mathrm{C}$ for the observation period of March 1997 to March 2008. The study site has been described in more detail by Haeberli et al. (1988); Hoelzle et al. (2002); Vonder Mühll et al. (2003); Schneider et al. (2012).

\subsection{Methods}

\subsection{Meteorological measurements}

The meteorological parameters air temperature, surface temperature, relative humidity, incoming and outgoing shortwave and longwave radiation, wind speed and snow height, are measured by a micrometeorological station directly at the study site (Mittaz et al., 2000; Hoelzle and Gruber, 2008). Data for this study have been measured at the station for the period from January 1997 to March 2008 in a 10 min interval and were stored as $30 \mathrm{~min}$ averages by the logger (see Table 1). Precipitation data were taken from a nearby station of MeteoSwiss, located at the summit of Piz Corvatsch. Data gaps in the on-site measurements, which are caused by lightning, avalanches, or hoarfrost, were reconstructed with measurements from the summit station, corrected by the use of correlation coefficients determined between the two stations. This completed meteorological data set consisting of incoming shortwave and longwave radiation, air temperature, wind speed, and relative humidity, and precipitation is used as input in the Coup Model (see Sect. 1.1). For the energy balance calculations the original data are left unchanged and only seasons with sufficient measurements are included in the analysis (see Results section).

\subsection{Energy balance}

Generally, the energy balance at seasonally snow-covered sites refers to a unit area and includes the net short-wave and long-wave radiation components, turbulent fluxes composed of sensible heat and latent heat, ground heat flux, melt energy of the snow, and heat flux through the snow cover. The corresponding energy balance (Williams and Smith, 1989) at such a site is given as

$Q_{\mathrm{rad}}+Q_{\mathrm{h}}+Q_{\mathrm{le}}+Q_{\mathrm{g}}+\Delta Q_{\mathrm{m}}+Q_{\mathrm{s}}=0$

where $Q_{\text {rad }}\left[\mathrm{W} \mathrm{m}^{-2}\right]$ is the net radiation, $Q_{\mathrm{h}}\left[\mathrm{W} \mathrm{m}^{-2}\right]$ is the sensible heat flux, $Q_{\text {le }}\left[\mathrm{W} \mathrm{m}^{-2}\right]$ is the latent heat flux, $Q_{\mathrm{g}}$ [W m$\left.{ }^{-2}\right]$ is the ground heat flux, $\Delta Q_{\mathrm{m}}\left[\mathrm{W} \mathrm{m}^{-2}\right]$ is the melt energy at the snow surface, and $Q_{\mathrm{s}}\left[\mathrm{W} \mathrm{m}^{-2}\right]$ is the heat flux through the snow cover. Following convention (Oke, 1988), heat fluxes towards the surface are denoted as positive and heat fluxes away from the surface are denoted as negative (see Fig. 2).

Due to the blocky surface layer at the Murtèl-Corvatsch rock glacier, in this study the energy balance within a volumetric blocky surface layer was studied. This contrasts with the approach of other energy balance studies, which refer to the energy balance of a two-dimensional unit area (see, e.g., Stocker-Mittaz, 2002; Westermann et al., 2009). 
a)

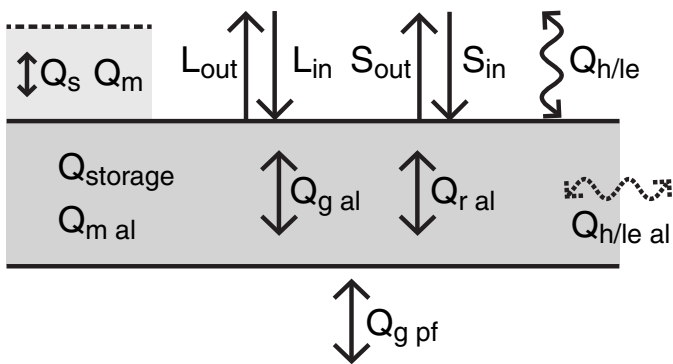

b)

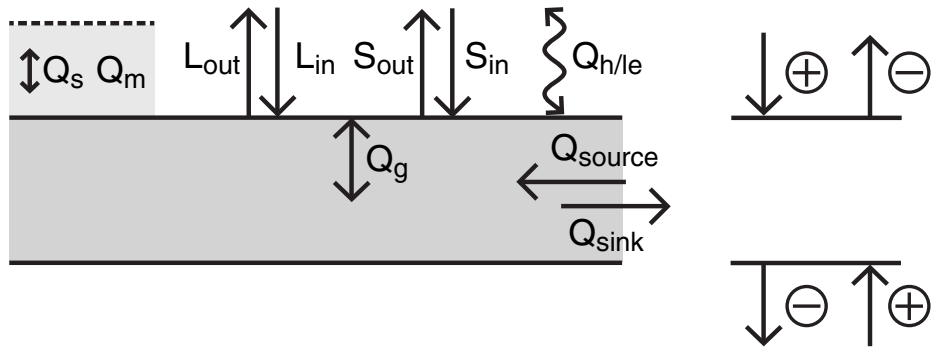

Figure 2. Illustration of the different energy exchange processes in (a) the energy balance calculations according to Eqs. (1-3) and (b) in the Coup Model. The scheme on the right-hand side shows the convention of positive and negative fluxes.

Processes within the blocky layer, added to the purely conductive ground heat flux usually applied, are convective or advective heat transfer by air flow in the voids between the blocks, net longwave radiation between adjacent blocks, melt and freezing energy within the active layer and at the permafrost table, and the heat storage change. The formulation of the energy balance term $Q_{\mathrm{g}}$ of Eq. (1) then becomes

$$
\begin{array}{r}
Q_{\mathrm{g}}=Q_{\mathrm{g}_{\mathrm{al}}}+Q_{\mathrm{g}_{\mathrm{pf}}}+Q_{\mathrm{le}_{\mathrm{al}}}+Q_{\mathrm{h}_{\mathrm{al}}}+Q_{\mathrm{rad}_{\mathrm{al}}} \\
-\Delta Q_{\text {storage }}-\Delta Q_{\mathrm{m}_{\mathrm{al}}}-\Delta Q_{\mathrm{m}_{\mathrm{pf}}},
\end{array}
$$

where $Q_{\mathrm{g}_{\mathrm{al}}}\left[\mathrm{W} \mathrm{m}^{-2}\right]$ is the conductive heat flux through the blocks of the active layer, $Q_{\mathrm{g}_{\mathrm{pf}}}\left[\mathrm{W} \mathrm{m}^{-2}\right]$ is the ground heat flux through the permafrost table, $Q_{\mathrm{le}_{\mathrm{al}}}\left[\mathrm{W} \mathrm{m}^{-2}\right]$ and $Q_{\mathrm{h}_{\mathrm{al}}}$ $\left[\mathrm{W} \mathrm{m}^{-2}\right]$ are the latent heat flux and the sensible heat flux in the voids between the blocks, $Q_{\mathrm{rad}_{\text {al }}}\left[\mathrm{W} \mathrm{m}{ }^{-2}\right]$ is the net radiative heat flux between the blocks, $\Delta Q_{\text {storage }}\left[\mathrm{W} \mathrm{m}^{-2}\right]$ is a source or sink term for heat energy in the blocks, and $\Delta Q_{\mathrm{m}_{\mathrm{al}}}$ [W m $\left.{ }^{-2}\right]$ and $\Delta Q_{\mathrm{m}_{\mathrm{pf}}}\left[\mathrm{W} \mathrm{m}^{-2}\right]$ are the melt/freezing energy used in the active layer and at the permafrost table.

Energy balance components were calculated on an hourly time step (except melt energy, for which $24 \mathrm{~h}$ intervals are used) and were then averaged to monthly and seasonal values (June-September; October-January; February-May) as shown in Fig. 3. The seasonality chosen reflects the periods in which the different three-dimensional energy exchange processes in the active layer are assumed to act in the same direction (e.g., cooling processes due to air circulation in October-January, enhanced heat flux through the active layer due to longwave radiation between the blocks from JuneSeptember). In the following the individual terms of Eqs. (1) and (2) are explained in detail.

\subsubsection{Radiative heat flux}

$Q_{\text {rad }}\left[\mathrm{W} \mathrm{m}^{-2}\right]$ is the net radiation at the surface and is calculated from direct radiation measurements at the micrometeorological station. The radiation measurements comprise incoming and outgoing short-wave and long-wave radiation:
$Q_{\mathrm{rad}}=L_{\downarrow}+S_{\downarrow}+L_{\uparrow}+S_{\uparrow}$

where $L\left[\mathrm{~W} \mathrm{~m}^{-2}\right]$ denotes longwave radiation and $S\left[\mathrm{~W} \mathrm{~m}^{-2}\right]$ denotes shortwave radiation.

The slope angle at the site was approximated by $10^{\circ}$, which reduces the radiation density on the surface. A further reduction in radiation density is expected due to surface roughness and shadow effects caused by the shape of the blocks. Therefore this value is corrected by a geometrical factor of 0.9. This factor is taken from a US patent 7305983 B1, which gives insolation information on inclined roofs. This information is gained by calculating the insolation depending on roof orientation and inclination of buildings in a GIS. The reduction found by these authors ranges from 95 to $50 \%$. We use a value of 0.9 , which represents a roof inclination of $35^{\circ}$ to $45^{\circ}$, depending on the orientation of the roof.

\subsubsection{Turbulent fluxes}

The turbulent heat fluxes within the blocks and at the surface blocky layer are calculated following the bulk method (Oke, 1988). The sensible heat flux, $Q_{\mathrm{h}}$, from the surface to the air is

$$
Q_{\mathrm{h}}=-C_{\mathrm{a}} \kappa^{2} z^{2}\left(\frac{\Delta \bar{u}}{\Delta z} \frac{\Delta \bar{T}}{\Delta z}\right)\left(\Phi_{M} \Phi_{H}\right)^{-1}
$$

where $C_{\mathrm{a}}\left[\mathrm{J} \mathrm{kg}^{-1} \mathrm{~K}^{-1}\right]$ is the specific heat capacity of air, $\kappa$ is the von Karman constant, $\Delta \bar{u}\left[\mathrm{~m} \mathrm{~s}^{-1}\right]$ is the wind speed gradient between sensor and ground surface, $\Delta z[\mathrm{~m}]$ is the height, $\Delta \bar{T}[\mathrm{~K}]$ is the temperature gradient between sensor and ground surface, $\Phi_{H}$ is a dimensionless stability function for heat and $\Phi_{M}$ is a dimensionless stability function to account for the curvature of the logarithmic wind profile due 
to buoyancy effects. $z$ is the log mean height calculated after Brock et al. (2010) as

$$
z=\ln \frac{\Delta h}{z_{0}} \times \ln \frac{\Delta h}{z_{0}}
$$

with $\Delta h(2 \mathrm{~m})$ being the height of the meteorological station and $z_{0}$ being the roughness length $(0.18 \mathrm{~m}$ for snow-free conditions and $0.07 \mathrm{~m}$ for snow-covered conditions as found by Stocker-Mittaz, 2002).

The latent heat flux at the ground surface is given by

$$
Q_{\mathrm{le}}=-\rho_{\mathrm{a}} L_{\mathrm{v}} \kappa^{2} z^{2}\left(\frac{\Delta \bar{u}}{\Delta z} \frac{\Delta \overline{\rho_{\mathrm{v}}}}{\Delta z}\right)\left(\Phi_{M} \Phi_{V}\right)^{-1},
$$

where $\rho_{\mathrm{a}}\left[\mathrm{kg} \mathrm{m}^{3}\right]$ is the density of air, $L_{\mathrm{v}}\left[\mathrm{kJ} \mathrm{kg}^{-1}\right]$ is the latent heat of evaporation, $\Delta \overline{\rho_{v}}\left[\mathrm{~kg} \mathrm{~kg}^{-1}\right]$ is the gradient in specific humidity between the ground surface and the humidity sensor at $2 \mathrm{~m}$ height, and $\Phi_{V}$ is a dimensionless stability function for vapor.

The stability functions in Eqs. (4) and (6) are calculated as:

in the stable case $\left(R_{i}\right.$ positive)

$\left(\Phi_{M} \Phi_{x}\right)^{-1}=\left(1-5 R_{i}\right)^{2}$

in the unstable case $\left(R_{i}\right.$ negative)

$\left(\Phi_{M} \Phi_{x}\right)^{-1}=\left(1-16 R_{i}\right)^{3 / 4}$,

where $\Phi_{x}$ is the respective stability function $\left(\Phi_{H}\right.$ or $\left.\Phi_{V}\right), R_{i}$ is the bulk Richardson number for categorizing atmospheric stability and the state of turbulence in the lower atmosphere calculated as

$R_{i}=\frac{g}{\bar{T}} \frac{(\Delta \bar{T} / \Delta z)}{(\Delta \bar{u} / \Delta z)^{2}}$,

where $g\left[\mathrm{~ms}^{-2}\right]$ is the acceleration due to gravity and $\bar{T}[\mathrm{~K}]$ is the mean temperature in the $\Delta z[\mathrm{~m}]$ layer.

\subsubsection{Melt energy}

The melt energy at the surface of the snow cover is calculated according to the difference in snow height in $24 \mathrm{~h}$ intervals, as measured by an ultrasonic sensor at the micrometeorological station (see Table 1). The threshold temperature for snowmelt is set to $-3^{\circ} \mathrm{C}$; below this temperature no snowmelt is calculated even if a decrease in snow height is measured. In addition, a measurement error is expected if the snow height decreases by more than $0.2 \mathrm{~m}$ in a $24 \mathrm{~h}$ interval. In this case, no snowmelt is calculated. Snow density has not been measured. Instead, a constant value of $300 \mathrm{~kg} \mathrm{~m}^{-3}$ was chosen according to Keller (1994), who found snow densities ranging from $250-400 \mathrm{~kg} \mathrm{~m}^{-3}$ at the same site. The melt energy is thus given as

$$
\Delta Q_{\mathrm{m}}=\frac{\Delta h \rho_{\mathrm{s}} L_{\mathrm{f}}}{\Delta t}
$$

where $\Delta h[\mathrm{~m}]$ is the difference in snow height, $\rho_{\mathrm{s}}\left[\mathrm{kg} \mathrm{m}^{3}\right]$ is the density of snow, $L_{\mathrm{f}}\left[\mathrm{kJ} \mathrm{kg}^{-1}\right]$ is the specific latent heat of fusion of water and $\Delta t[\mathrm{~s}]$ is the time interval.

\subsubsection{Ground heat flux}

The ground heat flux is calculated based on borehole temperature measurements at $0.55,1.55,2.55$ and $3.55 \mathrm{~m}$ depth assuming a thermal conductivity $k_{r}$ of $2.5 \mathrm{Wm}^{-2}$ in the Fourier heat conduction equation (see Eq. 11), which is considered to be appropriate for the solid metamorphic rocks found within the blocky layer. The values were then multiplied by a correction factor of 0.6 to account for the reduction in conductive heat fluxes within the air-filled pores between the blocks, corresponding to a porosity of $40 \%$ in the active layer. In contrast to the Coup Model simulations (see Sect. 1.1), changes in thermal conductivity due to water and ice content as well as latent heat processes are not accounted for here. Considering the low water retention capacity of the voids between the blocks, these parameters are supposed to be of minor importance for the thermal conductivity.

$Q_{g}=0.6 k_{r} \sum_{i=1}^{3} \frac{\Delta T_{i}}{\Delta z_{i}}$,

where $\Delta z_{i}$ are the respective layer thicknesses (here, $1 \mathrm{~m}$ ). The heat flux within the permafrost layer, $Q_{\mathrm{g}_{\mathrm{p}}}$, is calculated likewise using the thermal conductivity of ice and temperatures measured at 3.55 and $4.55 \mathrm{~m}$ depth during the winter period (October-January) and with a $3.55 \mathrm{~m}$ temperature fixed at $0{ }^{\circ} \mathrm{C}$ during the spring and summer period (FebruarySeptember). This is an assumption based on the concept that the lower boundary of the respective layer represents the permafrost table where thawing processes are supposed to keep the temperature at $0{ }^{\circ} \mathrm{C}$ during the summer period.

\subsubsection{Net radiation between adjacent blocks}

Due to the studied volumetric layer, a term accounting for radiative processes between the blocks due to temperature differences has been included in the energy balance (Eq. 2) (Kunii and Smith, 1960). The temperature gradient from the surface to the permafrost table leads to immediate heat flow from the warmer upper blocks to colder lower blocks in the active layer. This process is based on the emission and the absorption of thermal/longwave radiation between adjacent blocks of different temperature. The net flow of longwave radiation between two blocks with surface temperatures $T_{1}$ and $T_{2}$, which in this case are approximated by parallel plates, is given as

$q_{\text {net }}=\varepsilon_{\mathrm{eff}} \sigma\left(T_{1}^{4}-T_{2}^{4}\right)$,

where $q_{\text {net }}$ is the net longwave radiation, $\varepsilon$ is the emmisivity of the block (0.96) as determined by surface temperature and 
longwave radiation measurements, $T[\mathrm{~K}]$ is the absolute temperature, and $\sigma\left[\mathrm{W} \mathrm{m}^{-2} \mathrm{~K}^{-4}\right]$ is the Stefan-Boltzmann constant.

In the case of two opposite blocks with an emissivity of $\varepsilon<1$, the reflection of radiation has to be considered following McAdams (1954):

$\varepsilon_{1,2}=\frac{1}{\frac{1}{\varepsilon_{1}}+\frac{1}{\varepsilon_{2}}-1}=\frac{\varepsilon_{1} \varepsilon_{2}}{\varepsilon_{1}+\varepsilon_{2}-\varepsilon_{1} \varepsilon_{2}}$.

In the case where $\varepsilon_{1}$ equals $\varepsilon_{2}$, which is assumed for the blocks of the rock glacier, Eq. (13) becomes

$\varepsilon_{\text {eff }}=\frac{\varepsilon^{2}}{2 \varepsilon-\varepsilon^{2}}$.

The calculation is based on the borehole temperatures at $0.55,1.55,2.55$, and $3.55 \mathrm{~m}$. Errors might arise from too high gradients due to measurement depth intervals of $1 \mathrm{~m}$. Voids between individual blocks are assumed to be no larger than $0.33 \mathrm{~m}$ on average. The reduction in radiative heat flux between the blocks by a factor of 3 was chosen because of the temperature gradient within separate blocks, i.e., the block has a different temperature at its surface than what is measured by the thermistor within the block. Given a linear temperature gradient and equally spaced parallel plates, reduction by a factor of $1 / 3$ results.

\subsubsection{Snow heat flux}

The snow heat flux is the heat flux within the snow layer. It is calculated following the Fourier heat conduction equation

$Q_{\mathrm{s}}=k_{\mathrm{s}} \frac{T_{\mathrm{s}}-T_{0.55}}{0.55+h_{\mathrm{s}}}$,

where $T_{\mathrm{s}}\left[{ }^{\circ} \mathrm{C}\right]$ is the snow surface temperature, $T_{0.55}\left[{ }^{\circ} \mathrm{C}\right]$ is the temperature of the sensor at $0.55 \mathrm{~m} \mathrm{depth}, h_{\mathrm{s}}$ is the snow height and the thermal conductivity of snow $k_{\mathrm{s}}\left[\mathrm{W} \mathrm{m}{ }^{-1} \mathrm{~K}^{-1}\right.$ ] is calculated following Devaux (1933) (see also Keller, 1994; Stocker-Mittaz, 2002):

$k_{\mathrm{s}}=2.93\left(\frac{\rho_{\mathrm{s}}^{2}}{1000000}+0.1\right)$,

where $\rho_{\mathrm{s}}\left(300 \mathrm{~kg} \mathrm{~m}^{-3}\right)$ is the density of snow.

\subsubsection{Energy storage}

When looking at the energy balance of a volumetric layer the storage of energy has to be accounted for. The heating of blocks during the summer period will produce an energy sink term in the energy balance equation. The release of heat due to cooling of the blocks acts as an energy source in the balance equation (see Eq. 2). The storage change term is calculated as

$\Delta Q_{\text {storage }}=\frac{c_{\mathrm{r}} \Delta T m_{\mathrm{r}}}{\Delta t}$, a)

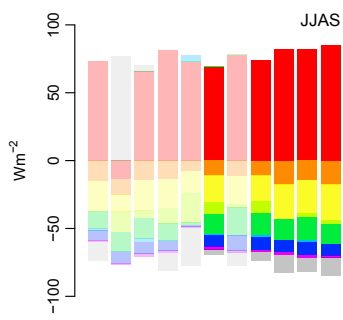

b)
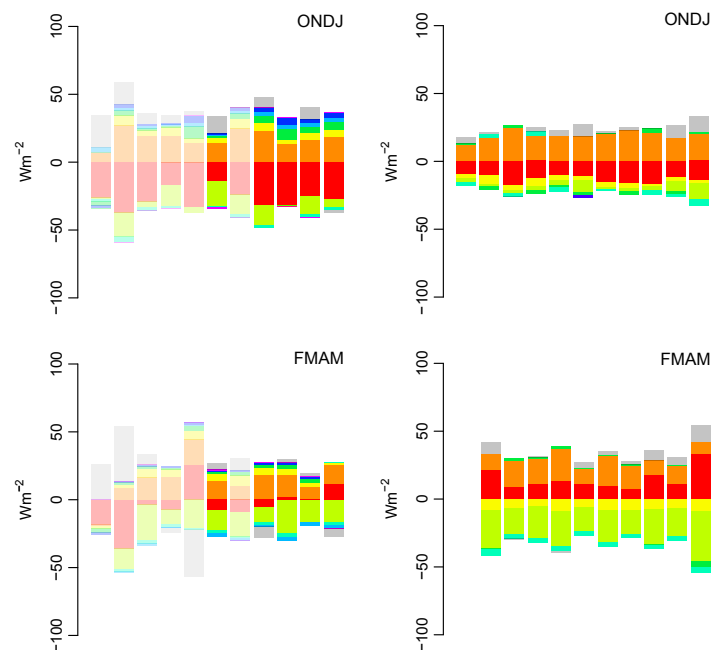

Figure 3. Seasonal energy balance components at the MurtèlCorvatsch rock glacier. (a) shows the observations and (b) shows the modeled components. Faded colors indicate years with incomplete measurements. $Q_{\text {rad }}$ : net radiation; $Q_{\mathrm{h}}$ : sensible heat flux at the surface; $Q_{\mathrm{le}}$ : latent heat flux at the surface; $\Delta Q_{\mathrm{m}}$ : melt energy in the snow cover; $Q_{\mathrm{s}}$ : conductive heat flux through the snow; $Q_{\mathrm{g}_{\mathrm{al}}} / Q_{\mathrm{g}}$ : conductive heat flux within the active layer (a)/ through the surface (b); $Q_{\text {radal }_{\text {al }}}$ : net radiation in the active layer; $\Delta Q_{\text {storage }}$ : change in heat content in the active layer; $Q_{\mathrm{tal}}$ : turbulent heat flux in the active layer; $Q_{\mathrm{g}_{\mathrm{pf}}}$ : conductive heat flux through the permafrost table; dev: energy balance closure. The seasons are divided into: JuneSeptember (JJAS), October-January (ONDJ) and February-May (FMAM)

where $c_{\mathrm{r}}\left[\mathrm{J} \mathrm{kg}^{-1} \mathrm{~K}^{-1}\right]$ is the specific heat capacity of rock, $\Delta T$ $[\mathrm{K}]$ is the daily temperature difference and $m_{\mathrm{r}}[\mathrm{kg}]$ is the rock mass. The porosity of the blocky layer is assumed to be $40 \%$.

Results

\subsection{Energy balance}

Figure 3 and tables 2, 3, and 4 show the seasonal energy balances at the study site from 1997 to 2007. Figure 3a shows the measured energy balance components, Fig. 3b shows the modeled energy balance components. In the measured energy balance, the following criteria were used to select seasons to be excluded in the energy balance calculations: (1) seasons with too many missing values overall (>30\%), (2) seasons missing important variables (i.e., sur- 
Table 2. Seasonal (June-September) averages of the energy balance components with deviations (in $\mathrm{Wm}^{-2}$ ) and corresponding ice thickness equivalents (in m). Years marked with an asterik were not considered for the calculation of the average and the standard deviation. $Q_{\text {rad }}$ Net radiation; $Q_{\mathrm{h}}$ : Sensible heat flux at the surface; $Q_{\mathrm{le}}$ : Latent heat flux at the surface; $\Delta Q_{\mathrm{m}}$ : Melt energy in the snow cover; $Q_{\mathrm{s}}$ : Conductive heat flux through the snow; $Q_{\mathrm{gal}_{\mathrm{al}}}$ : Conductive heat flux within the active layer; $Q_{\mathrm{rad}_{\mathrm{al}}}$ : Net radiation in the active layer; $\Delta Q_{\text {storage }}$ : Change in heat content in the active layer; $Q_{\mathrm{t}_{\mathrm{al}}}$ : Turbulent heat flux in the active layer; $Q_{\mathrm{g}_{\mathrm{p}}}$ : Conductive heat flux through the permafrost table; dev: Energy balance closure; ice: Ice melt equivalent of the energy balance closure.

\begin{tabular}{lrrrrrrrrrrrr}
\hline Year & $Q_{\mathrm{rad}}$ & $Q_{\mathrm{h}}$ & $Q_{\mathrm{le}}$ & $\Delta Q_{\mathrm{m}}$ & $Q_{\mathrm{s}}$ & $Q_{\mathrm{gal}}$ & $Q_{\mathrm{rad}_{\mathrm{al}}}$ & $\Delta Q_{\text {storage }}$ & $Q_{\mathrm{al}}$ & $Q_{\mathrm{g}_{\mathrm{pf}}}$ & $\mathrm{dev}$ & ice \\
\hline $1997^{*}$ & 73.7 & -15.2 & -22.2 & - & - & -12.6 & -6.9 & -1.5 & -0.5 & -1.1 & -13.7 & -0.47 \\
$1998^{*}$ & - & -11.7 & -12.5 & -15.0 & 0.0 & -14.4 & -7.9 & -0.3 & -0.5 & -1.2 & 63.6 & 2.19 \\
$1999^{*}$ & 65.9 & -14.1 & -22.6 & -5.5 & 0.0 & -15.4 & -8.5 & -2.3 & -0.5 & -1.6 & 4.6 & 0.16 \\
$2000^{*}$ & 81.1 & -13.8 & -20.8 & -11.6 & 0.0 & -12.8 & -7.1 & 0.0 & -0.5 & -1.3 & -13.0 & -0.45 \\
$2001^{*}$ & 72.8 & -7.9 & -16.0 & -21.8 & 0.2 & -1.8 & -1.0 & 4.5 & -0.5 & -0.6 & -28.0 & -0.96 \\
2002 & 69.4 & -11.2 & -19.5 & -8.7 & 0.1 & -15.0 & -8.2 & -0.8 & -0.5 & -1.8 & -3.9 & -0.13 \\
$2003^{*}$ & 77.8 & -11.3 & -20.5 & -2.7 & 0.0 & -20.4 & -11.2 & -0.3 & -0.5 & -1.0 & -10.1 & -0.35 \\
2004 & 74.1 & -11.0 & -18.8 & -8.6 & 0.0 & -16.7 & -9.2 & -1.3 & -0.5 & -1.3 & -6.6 & -0.23 \\
2005 & 82.4 & -17.7 & -25.8 & - & - & -15.1 & -8.3 & -0.3 & -0.5 & -1.7 & -13.1 & -0.45 \\
2006 & 81.9 & -14.3 & -24.3 & -3.3 & - & -17.0 & -9.3 & -1.4 & -0.5 & -1.8 & -10.1 & -0.35 \\
2007 & 84.9 & -17.6 & -26.5 & -2.8 & 0.0 & -14.8 & -8.1 & -0.1 & -0.5 & -1.1 & -13.5 & -0.46 \\
\hline Average & 78.5 & -14.3 & -23.0 & -5.9 & 0.0 & -15.7 & -8.6 & -0.8 & -0.5 & -1.4 & -9.4 & -0.32 \\
Stdev & 5.8 & 2.9 & 3.2 & 2.8 & 0.1 & 0.9 & 0.5 & 0.5 & 0.0 & 0.3 & 3.7 & 0.13 \\
\hline
\end{tabular}

face temperature $T_{\text {ir }}$ or long- and shortwave radiation), and (3) complete years with two missing seasons following the above criteria. The long-term seasonal average energy balance is shown in Fig. 4. Measured and simulated energy balances differ significantly in most of the terms. Radiative heat flux at the surface is smaller in the model than in the measurements in the summer and winter seasons, whereas sensible heat flux is larger in the respective seasons. Latent heat is larger by a factor of 2 in the measurements compared to the simulation. In the model latent heat is always negative, i.e., flowing away from the surface. Melt energy is larger in the model during summer and equal from February to May.

Both measured and simulated energy balances have deviation terms to close the energy balance to zero. The deviations may arise from various sources that can differ between model and measurements; see also the corresponding Sect. 3.1.9 in the Discussion.

Seasonal deviation terms of the measurements (only complete measurement years considered) range from $16.9 \mathrm{Wm}^{-2}$ in October-February (Table 3) to $-13.3 \mathrm{Wm}^{-2}$ in FebruaryMay (Table 4). Deviation terms in the model range from $31.9 \mathrm{Wm}^{-2}$ in June-September to $-1.0 \mathrm{Wm}^{-2}$ in FebruaryMay (see Fig. 3). The sum of the average seasonal deviations of the measurements (see tables 2,3, and 4) is equal to a net melt/refreezing rate of $-0.10 \mathrm{~m} \mathrm{a}^{-1}$ of ice in the blocky layer. This is comparable to the net melt rate of $-0.05 \mathrm{~m} \mathrm{a}^{-1}$ found by Kääb et al. (1998) for the same site.

\subsection{Simulation of the thermal regime}

Figure 6 shows the measured and the simulated temperatures at two depths for the simulated period. The green lines in
Fig. 6 show the results for the simulation with only meteorological measurement input and the red lines the results with measured meteorological input as well as an additional seasonal heat source and heat sink in the active layer representing advective and radiative heat fluxes. It can be seen that in the case where no additional heat source or sink is active, thermal conditions do not favor the development of permafrost if local meteorological data is used to drive the model. Temperatures are well above $0{ }^{\circ} \mathrm{C}$ in summer down to $11 \mathrm{~m}$ below the surface, indicating that permafrost is not present in this simulation. In the other case with an additional heat source and sink, permafrost is present at the respective depths. The values found by experimental calibration are about $28.9 \mathrm{Wm}^{-2}$ for the heat sink during the period from mid September to mid January. The heat source in the period from June to mid September amounts to $26 \mathrm{Wm}^{-2}$.

\section{Discussion}

\subsection{Uncertainties in the energy balance measurements}

Regarding the energy balance measurements, there are some general points that need to be addressed. First, the categorization of seasons may be based on prevailing meteorological conditions, processes in the active layer or a combination of both (Westermann et al., 2009; Langer et al., 2011; Schneider et al., 2012). Here, three seasons, approximately based on the heat source and heat sink seasons in the model, were differentiated. This may lead to problems in so far as processes may occur in multiple seasons to different proportions depending on meteorological conditions on the one hand and may counteract each other on the other hand. Thus, an interpretation 
Table 3. Seasonal (October-January) averages of the energy balance components with deviations (in $\mathrm{Wm}^{-2}$ ) and corresponding ice thickness equivalents (in m). Years marked with an asterik were not considered for the calculation of the average and the standard deviation. $Q_{\text {rad }}$ : Net radiation; $Q_{\mathrm{h}}$ : Sensible heat flux at the surface; $Q_{\mathrm{le}}$ : Latent heat flux at the surface; $\Delta Q_{\mathrm{m}}$ : Melt energy in the snow cover; $Q_{\mathrm{s}}$ : Conductive heat flux through the snow; $Q_{\mathrm{gal}_{\mathrm{al}}}$ : Conductive heat flux within the active layer; $Q_{\mathrm{rad}_{\mathrm{al}}}$ : Net radiation in the active layer; $\Delta Q_{\mathrm{storage}}$ : Change in heat content in the active layer; $Q_{\mathrm{t}_{\mathrm{al}}}$ : Turbulent heat flux in the active layer; $Q_{\mathrm{g}_{\mathrm{pf}}}$ : Conductive heat flux through the permafrost table; dev: Energy balance closure; ice: Ice melt equivalent of the energy balance closure.

\begin{tabular}{lrrrrrrrrrrrr}
\hline Year & $Q_{\mathrm{rad}}$ & $Q_{\mathrm{h}}$ & $Q_{\mathrm{le}}$ & $\Delta Q_{\mathrm{m}}$ & $Q_{\mathrm{s}}$ & $Q_{\mathrm{gall}_{1}}$ & $Q_{\mathrm{radal}}$ & $\Delta Q_{\text {storage }}$ & $Q_{\mathrm{tal}}$ & $Q_{\mathrm{gp}_{\mathrm{pf}}}$ & $\mathrm{dev}$ & ice \\
\hline $1997^{*}$ & -25.9 & 6.6 & 0.6 & -1.3 & -1.6 & -3.3 & -1.9 & 3.8 & - & -0.6 & 23.6 & 0.82 \\
$1998^{*}$ & -37.0 & 26.8 & 7.6 & -17.7 & -4.2 & 3.7 & 2.2 & 1.7 & - & -0.1 & 16.7 & 0.58 \\
$1999^{*}$ & -29.0 & 18.9 & 4.4 & -4.1 & -2.2 & 1.5 & 1.1 & 2.1 & - & -0.4 & 7.7 & 0.27 \\
$2000^{*}$ & -16.9 & 19.2 & 6.1 & -15.2 & -1.5 & 1.4 & 1.1 & 1.1 & - & -0.6 & 5.2 & 0.18 \\
$2001^{*}$ & -33.0 & 14.1 & 3.4 & -4.3 & 0.0 & 8.9 & 5.0 & 2.8 & - & 0.7 & 2.4 & 0.08 \\
2002 & -14.2 & 14.0 & 4.1 & -18.2 & -0.8 & 1.3 & 1.1 & 0.9 & - & -0.9 & 12.7 & 0.44 \\
$2003^{*}$ & -24.0 & 25.0 & 6.7 & -14.1 & -2.7 & 4.1 & 2.6 & 2.2 & - & -0.1 & 0.2 & 0.01 \\
2004 & -32.1 & 23.5 & 5.4 & -14.3 & -1.6 & 5.4 & 3.2 & 3.0 & - & 0.1 & 7.5 & 0.26 \\
2005 & -32.1 & 13.3 & 3.3 & -0.3 & - & 7.8 & 5.0 & 3.1 & - & 0.1 & -0.3 & -0.01 \\
2006 & -24.8 & 16.7 & 5.2 & -13.6 & -1.8 & 4.3 & 2.8 & 2.9 & - & -0.5 & 8.9 & 0.31 \\
2007 & -26.9 & 18.8 & 4.8 & -6.6 & -1.6 & 6.5 & 4.0 & 2.4 & - & 0.2 & -1.5 & -0.05 \\
\hline Average & -26.0 & 17.2 & 4.5 & -10.6 & -1.5 & 5.1 & 3.2 & 2.4 & - & -0.2 & 5.5 & 0.19 \\
Stdev & 6.6 & 3.7 & 0.7 & 6.4 & 0.4 & 2.2 & 1.3 & 0.8 & - & 0.4 & 5.5 & 0.23 \\
\hline
\end{tabular}

of typical processes within a season is difficult. Nevertheless, some characteristics in the magnitude and the direction of individual energy balance components are obvious. Also, the deviations show seasonal similarities and may even be interpreted as freezing and thawing processes due to their directions. Finally, it also has to be considered that data gaps, random measurement errors and parametrizations may have a significant influence on the results presented herein.

In the following, potential sources of error calculation of the individual energy balance components are discussed in detail.

\subsubsection{Net radiation}

The factor by which measured incoming radiation is reduced is $\cos 10^{\circ}$ and a correction factor of 0.9 , which is assumed to account for both slope and surface geometry. As radiative heat flux at the surface is a very important term in the energy balance, small errors in the geometrical correction factor may lead to uncertainties. A further source of error is a possible underestimation of radiation density during the snowcovered season due to a snow cover on the upward looking sensor.

\subsubsection{Turbulent fluxes at the surface}

Turbulent fluxes, as calculated following Eqs. (4) and (6), are strongly dependent on wind speed, which is generally very low at the site. In the model an enhancing parameter is used that avoids effects of extreme stable stratification during periods of low wind speeds. This may lead to an overestimation of turbulent fluxes in the model. Furthermore, saturated conditions at the ground surface were assumed for the calculation of the latent heat flux, which is probably a reasonable choice for the depressions between the blocks of a rock glacier, but may lead to an overestimation for the dry conditions at the top of the blocks. Eddy covariance measurements, which were not available at the study site, would certainly improve the calculations.

\subsubsection{Melt energy}

The calculation of melt energy based solely on snow height measurements and assuming a constant snow density, as it was done in this study, may lead to errors. Snow density will certainly vary over the winter period in nature, reaching a peak in spring with the beginning of snowmelt. So, with the assumption of a constant snow density, melt rates will be overestimated in the beginning of winter, when snow is less dense, and underestimated in late winter and spring when snow is probably denser than $300 \mathrm{~kg} \mathrm{~m}^{-3}$. Refreezing of melted snow within the snow cover will lead to more melt than would be expected by measurements of the difference in snow heights. Settlement of snow might be mistaken for melt when occurring above the threshold temperature of $-3{ }^{\circ} \mathrm{C}$. During a $24 \mathrm{~h}$ period snowmelt and snowfall may occur (snowfall in the morning, snowmelt in the afternoon), which is not considered in the calculations. This situation is most likely to occur in the melting period from April to July and during the summer season. Thus the values calculated for the respective period are likely to be too low. It has to be considered that snow density estimation above permafrost is complicated, because of low ground temperatures that lead to a different snow densification pattern in spring than would 
Table 4. Seasonal (February-May) averages of the energy balance components with deviations (in $\mathrm{Wm}^{-2}$ ) and corresponding ice thickness equivalents (in m). Years marked with an asterik were not considered for the calculation of the average and the standard deviation. $Q_{\text {rad }}$ Net radiation; $Q_{\mathrm{h}}$ : Sensible heat flux at the surface; $Q_{\mathrm{le}}$ : Latent heat flux at the surface; $\Delta Q_{\mathrm{m}}$ : Melt energy in the snow cover; $Q_{\mathrm{s}}$ : Conductive heat flux through the snow; $Q_{\mathrm{gal}_{\mathrm{al}}}$ : Conductive heat flux within the active layer; $Q_{\mathrm{rad}_{\mathrm{al}}}$ : Net radiation in the active layer; $\Delta Q_{\text {storage }}$ : Change in heat content in the active layer; $Q_{\mathrm{t}_{\mathrm{al}}}$ : Turbulent heat flux in the active layer; $Q_{\mathrm{g}_{\mathrm{pf}}}$ : Conductive heat flux through the permafrost table; dev: Energy balance closure; ice: Ice melt equivalent of the energy balance closure.

\begin{tabular}{lrrrrrrrrrrrr}
\hline Year & $Q_{\mathrm{rad}}$ & $Q_{\mathrm{h}}$ & $Q_{\mathrm{le}}$ & $\Delta Q_{\mathrm{m}}$ & $Q_{\mathrm{s}}$ & $Q_{\mathrm{gal}_{\mathrm{al}}}$ & $Q_{\mathrm{radal}_{\mathrm{al}}}$ & $\Delta Q_{\text {storage }}$ & $Q_{\mathrm{tal}}$ & $Q_{\mathrm{g}_{\mathrm{pf}}}$ & $\operatorname{dev}$ & ice \\
\hline $1997^{*}$ & -18.4 & -1.2 & -1.5 & - & - & -3.2 & -1.7 & - & - & 0.1 & 25.9 & 0.88 \\
$1998^{*}$ & -36.1 & 8.8 & 2.0 & -14.9 & -1.8 & 1.9 & 1.0 & -1.0 & - & 0.2 & 40.1 & 1.36 \\
$1999^{*}$ & -3.4 & 16.5 & 6.0 & -26.4 & -2.3 & 2.0 & 1.0 & -1.8 & - & 0.5 & 7.8 & 0.26 \\
$2000^{*}$ & -7.3 & 16.7 & 5.4 & -10.7 & -2.1 & 1.4 & 0.8 & -0.4 & - & -0.1 & -3.7 & -0.12 \\
$2001^{*}$ & 25.7 & 18.7 & 6.6 & -20.7 & -1.2 & 3.5 & 2.0 & 0.6 & - & 0.3 & -35.3 & -1.20 \\
2002 & -7.8 & 14.3 & 4.9 & -14.7 & -2.4 & 1.5 & 0.5 & -2.3 & - & 0.9 & 5.1 & 0.17 \\
$2003^{*}$ & -9.0 & 10.2 & 7.7 & -18.1 & -1.1 & 2.2 & 1.3 & -2.1 & - & 0.0 & 8.9 & 0.30 \\
2004 & -5.5 & 18.6 & 4.7 & -11.0 & -2.1 & 2.8 & 1.5 & -1.2 & - & 0.5 & -8.2 & -0.28 \\
2005 & 2.1 & 16.2 & 4.2 & -24.7 & -2.9 & 2.9 & 1.4 & -2.6 & - & 0.6 & 2.7 & 0.09 \\
2006 & -0.3 & 9.5 & 3.0 & -16.4 & - & 3.1 & 1.6 & -2.6 & - & 0.4 & 1.9 & 0.06 \\
2007 & 12.2 & 13.4 & 1.8 & -16.7 & -2.2 & 0.2 & -0.2 & -2.0 & - & -0.3 & -6.3 & -0.21 \\
\hline Average & 0.1 & 14.4 & 3.7 & -16.7 & -2.4 & 2.1 & 1.0 & 2.1 & - & 0.3 & -0.9 & -0.03 \\
Stdev & 7.0 & 3.0 & 1.2 & 4.5 & 0.3 & 1.1 & 0.7 & 0.5 & - & 0.3 & 5.3 & 0.18 \\
\hline
\end{tabular}

be expected for non-permafrost sites. Keller (1994) showed that snow with lower densities than the one used herein can be found above mountain permafrost. Thus the value chosen is considered a good approximation for the average density over the entire snow-covered period.

\subsubsection{Ground heat flux}

The strong influence of the thermal conductivity on the conductive heat flux may lead to significant uncertainties. Further uncertainties are added due to the unknown porosity (fraction of blocks to air-filled voids) of the blocky layer, the position of the thermistors in the borehole and the reduction factor chosen in this study.

\subsubsection{Net radiation between adjacent blocks}

The calculation of the thermal radiation between adjacent blocks in this study is based on the assumption of three equally large quadratic blocks with an area $1 \mathrm{~m}^{2}$ parallel stacked with a spacing of $0.33 \mathrm{~m}$. The surface temperatures are assumed to be equal to the temperatures measured at $0.55 \mathrm{~m}, 1.55,2.55$, and $3.55 \mathrm{~m}$. The reduction by a factor of $1 / 3$, as described in the Methods section, accounts for this rough estimation, which may lead to significant uncertainties, especially in seasons with large thermal gradients.

\subsubsection{Snow heat flux}

Using the temperature at $0.55 \mathrm{~m}$ depth instead of the ground surface temperature in Eq. (15) may lead to errors, which can be considered as small due to nearly isothermal conditions in the active layer during the snow-covered period.

\subsubsection{Energy storage}

Errors in the calculation of the energy storage change may be due to assumption of the rock mass, varying rock density and heat capacity as well as borehole temperature measurements.

\subsubsection{Turbulent fluxes between blocks}

Measurements for the calculations were only available for the time period of mid June to mid July 2006, thus values available for the respective period have been taken for the complete summer season of June to September. Values for the other two seasons were not available and are missing in the energy balance. This may produce significant errors in the energy balance in the fall period, where these processes have been shown to be large due to the advection of cold air (Panz, 2006).

\subsubsection{Energy balance closure}

In the model the energy balance is not supposed to be closed due to convective heat transfer by precipitation and snow as well as surface runoff. In the measurements there are other sources of error. Besides the effects of radiative, convective and advective heat transfer, which are the subject of this study and are thus expected to cause deviations, there are other sources of error, such as direct measurement errors at the meteorological station, i.e., icing and snow at radiation sensors (see Table 1). Finally, unmeasured freezing and thawing processes within the blocky surface layer can add significant uncertainties to the energy balance.

When summing up all energy balance components following Eq. (1) and considering the energy exchange processes 

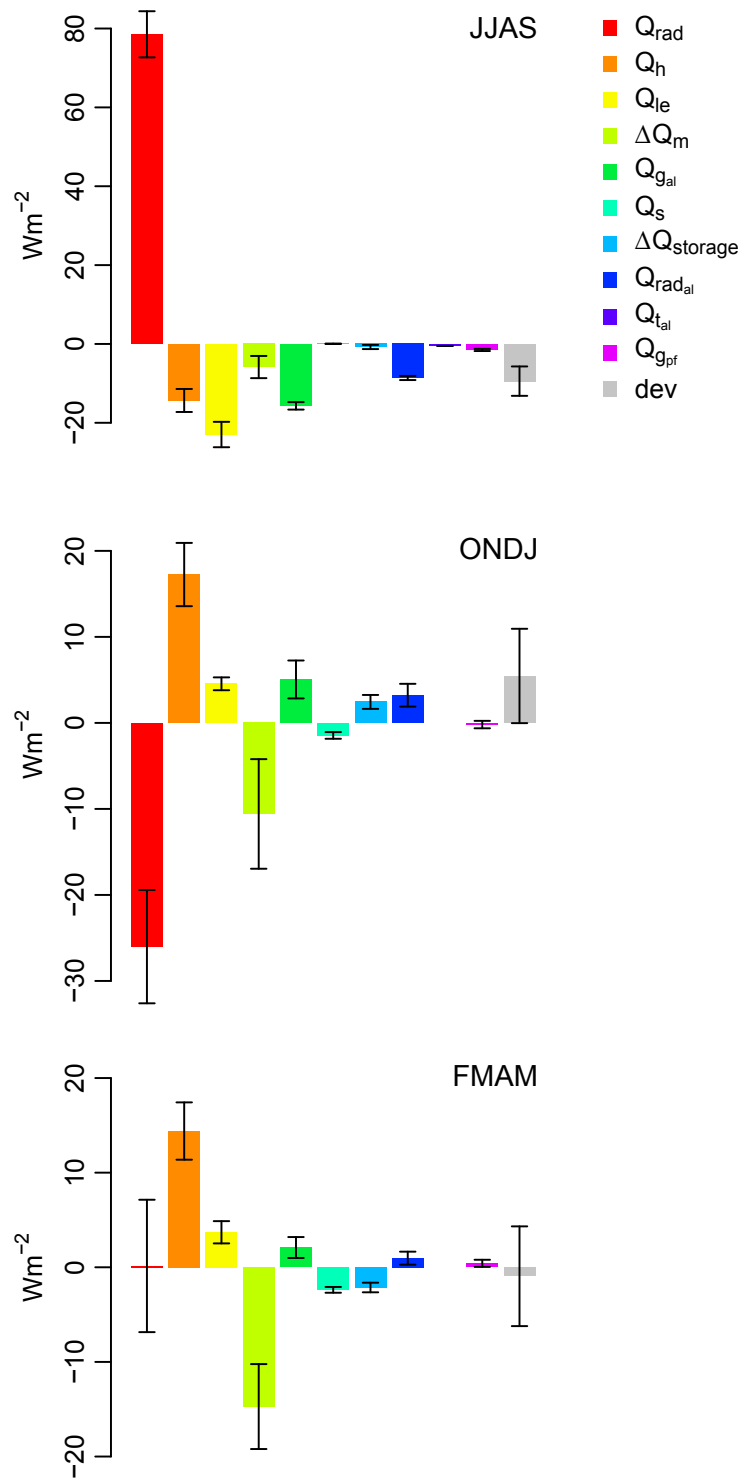

Figure 4. 5-year averages (with corresponding standard deviations) of the seasonal energy balance components at the Murtèl-Corvatsch rock glacier. $Q_{\text {rad }}$ : net radiation; $Q_{\mathrm{h}}$ : sensible heat flux at the surface; $Q_{\mathrm{le}}$ : latent heat flux at the surface; $\Delta Q_{\mathrm{m}}$ : melt energy in the snow cover; $Q_{\mathrm{s}}$ : conductive heat flux through the snow; $Q_{\mathrm{gal}_{1}}$ : conductive heat flux within the active layer; $Q_{\mathrm{rad}_{\mathrm{al}}}$ : net radiation in the active layer; $\Delta Q_{\text {storage }}$ : change in heat content in the active layer; $Q_{\mathrm{tal}_{\mathrm{al}}}$ : turbulent heat flux in the active layer; $Q_{\mathrm{g}_{\mathrm{pf}}}$ : conductive heat flux through the permafrost table; dev: energy balance closure. The seasons are divided into: June-September (JJAS), October-January (ONDJ) and February-May (FMAM).

in the blocky layer following Eq. (2) we assume that the result should be zero. As the two terms $\Delta Q_{\mathrm{m}_{\mathrm{al}}}$ and $\Delta Q_{\mathrm{m}_{\mathrm{pf}}}$ in Eq. (2) as well as the magnitude of the lateral turbulent fluxes in the active layer are unknown, Eq. (1) will have a deviation term to a zero energy balance. Random measurement errors and uncertainties in the parametrization of the energy balance component calculations will also add up to the total deviation term. Assuming that the random measurement errors and the parametrization uncertainties will even out over the studied time period, the deviation term could be interpreted as an indirect measure of the magnitude of the unmeasured processes in the blocky surface layer. If it is hypothesized that the missing processes are mainly associated with freezing and thawing of water in the active layer $\left(\Delta Q_{\mathrm{m}_{\mathrm{al}}}\right)$ and at the permafrost table $\left(\Delta Q_{\mathrm{m}_{\mathrm{pf}}}\right)$, then the sum of the deviation terms would be an indirect measure of net melt or net refreezing rates. This result can then be compared to the net melt rate found in a study by Kääb et al. (1998) based on geodetic measurements as well as calculations of the vertical deformation of the rock glacier mass over the period from 1987 to 1996 . The value $-0.05 \mathrm{~m}$ per year found by Kääb et al. (1998) is smaller than the one of $-0.17 \mathrm{~m}$ found in this study. This discrepancy may be due to measurement and parametrization errors as well as missing lateral fluxes on the one hand and/or a real increase in the net melt rate caused by a warmer climate in recent years on the other. The IPCC (IPCC, 2013) reports an average global surplus in anthropogenic radiative forcing of $2.29 \mathrm{Wm}^{-2}$ over the industrial era, which would correspond to a net melt rate of $0.24 \mathrm{~m}$ per year.

\subsection{Model}

The values found for the heat source and sink layer by calibrating the model to match observed borehole temperatures have to be treated with care because the source/sink layer is $1 \mathrm{~m}$ thick and placed close to the surface. This means that the heat extracted or added is transferred to larger depths (i.e., the depths shown in Fig. 6) by conduction and percolating water. This transfer will not act immediately on the temperatures at depth, but will take some time. In nature however the heat transfer by thermal radiation as well as convection and advection of air in the voids between the blocks may act more directly on the thermal regime in the permafrost below. Because of this phase shift in heat transfer it is possible that the timing of the heat source/sink in the layer, located near the surface, is not identical to the timing of the processes in nature. Furthermore it is not likely that the three-dimensional heat transfer within the blocky layer will be constant over periods of four consecutive months, as it is assumed for the parametrization of the model. The approach chosen to calibrate a process-based soil model in this study differs from similar model studies on sites with coarse debris cover (e.g., Gruber and Hoelzle, 2008). The presented solution with a heat source and sink layer is considered to be useful as an additional instrument for both the calibration of the model and for an approximate quantification of three-dimensional heat transfer within the active layer. 


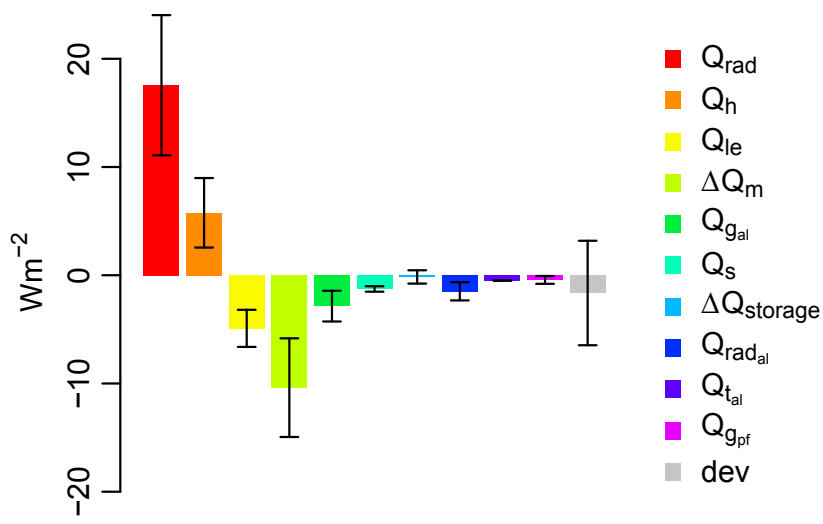

Figure 5. 5-year averages over all three seasons (with corresponding standard deviations) of the energy balance components at the Murtèl-Corvatsch rock glacier. $Q_{\text {rad }}$ : net radiation; $Q_{\mathrm{h}}$ : sensible heat flux at the surface; $Q_{\mathrm{le}}$ : latent heat flux at the surface; $\Delta Q_{\mathrm{m}}$ : melt energy in the snow cover; $Q_{s}$ : conductive heat flux through the snow; $Q_{\mathrm{g}_{\mathrm{al}}}$ : conductive heat flux within the active layer; $Q_{\mathrm{rad}_{\mathrm{al}}}:$ net radiation in the active layer; $\Delta Q_{\text {storage }}$ : change in heat content in the active layer; $Q_{\mathrm{t}_{\mathrm{al}}}$ : turbulent heat flux in the active layer; $Q_{\mathrm{g}_{\mathrm{p}}}$ : conductive heat flux through the permafrost table; dev: energy balance closure.

\subsection{Synopsis}

Besides energy balance studies as presented herein, the indirect approach for the quantification of three-dimensional heat transfer by air circulation and longwave radiation by applying a heat source and sink layer in a permafrost model can serve as an additional instrument in the investigation of such processes. The direct comparison of model parameters for the heat sink and source with the deviations found in energy balance measurements is difficult to interpret because of possible measurement errors on the one hand and process simplification in the model on the other. The comparison of the measured and the simulated energy balance reveals large differences for some of the components, especially the sensible heat flux during the summer season. This can be attributed to the different reference units (unit area versus volumetric surface layer) in the model and the measurements and to a correction parameter in the Coup Model, which enhances turbulent exchange during periods with low wind speeds. Measured energy fluxes are studied in a volumetric surface layer that includes processes such as radiative heat transfer between blocks in the nature. As such processes are not integrated in the model; they are likely to be compensated by other heat transfer mechanisms. A surplus of energy at the surface in the model will not completely be transferred to the ground, but will rather be emitted to the atmosphere by turbulent fluxes and longwave radiation. This difference will be most significant in the summer season, as typically measured wind speeds tend to be low during this period. In the model turbulent fluxes are enhanced by a correction parameter during such conditions.

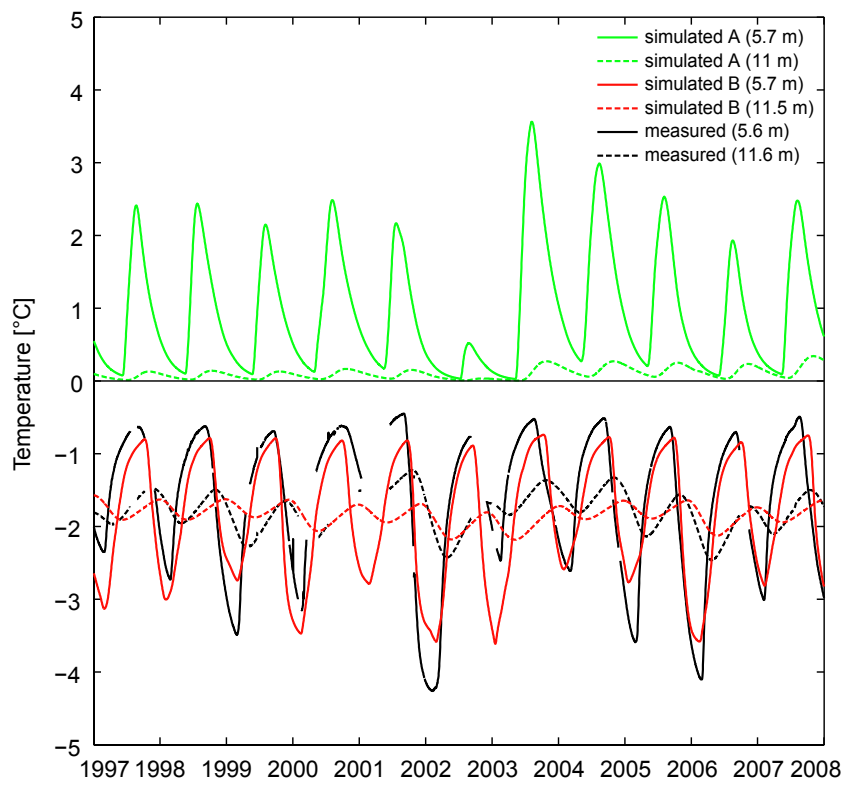

Figure 6. Simulated and measured temperatures at the MurtèlCorvatsch rock glacier showing the calibration without (simulated A) and with thee source/sink term (simulated B) at depths of 5.6 and $11.5 \mathrm{~m}$ below the surface, within the permafrost layer.

However, similarities can be found in the direction of the heat flow processes found in the energy balance measurements, i.e., the radiative heat transfer between the blocks of the active layer and the deviation term, and the parametrization of the heat source/sink layer. The value found for the heat source found by the calibration was $26 \mathrm{Wm}^{-2}$, and the respective energy flow in the measurements (radiative heat flux and deviation) is $-18.1 \mathrm{Wm}^{-2}$, which means that energy used to melt ice in the active layer in the measurements and in the model energy has to be added to the system to account for this additional melt. During the heat sink period in the model, $28.9 \mathrm{Wm}^{-2}$ are extracted from the system, which corresponds to $8.7 \mathrm{Wm}^{-2}$ surplus in the measurements. The differences between the amount of energy in the two approaches could be explained by an excess of heat flow from the surface during the summer season in the model and by missing lateral energy fluxes in the measurements during summer and winter.

\section{Conclusions}

In this study we applied a numerical soil model integrating freezing and thawing processes and a dynamical snow cover to simulate a 13-year period of the active layer and the permafrost at the Murtèl-Corvatsch rock glacier in the Upper Engadine, Swiss Alps. Other than considering the blocky layer with voids as a thermal semi-conductor, a different approach is presented, which integrates a heat source and sink into the active layer. A measured energy balance over 
a volumetric surface layer including terms for radiative heat transfer between adjacent blocks, turbulent fluxes in the active layer and energy storage change is presented and compared to the modeled energy balance at the site. The deviations in the measured energy balance were used indirectly to quantify unmeasured latent heat processes involving freezing and thawing processes in the active layer and at the permafrost table.

- The approach chosen to calibrate a process-based soil model differs from similar model studies on sites with coarse debris cover. The presented solution with a heat source and sink layer is considered to be useful for both the calibration of the model and the approximate quantification of three-dimensional heat transfer processes within the active layer, which so far cannot be modeled explicitly.

- The unmeasured heat transfer processes within the blocky active layer could be approximated in the model to act as a heat sink of $28.9 \mathrm{Wm}^{-2}$ during a period from mid September to mid January and as a heat source in the period from June to mid September of $26 \mathrm{Wm}^{-2}$.

- Measured and simulated energy balances differ significantly. The differences can partly be attributed to the different reference units (i.e., a unit area in the model and a volumetric surface layer in the measurements) and thus different energy exchange processes.

- The integration of additional energy balance components reduced the deviations to a zero energy balance significantly compared to earlier studies at the same site (Mittaz et al., 2002).

- The remaining deviations in the measured energy balance are hypothesized to be due to latent heat effects (i.e., freezing and thawing) in the active layer and at the permafrost table. This hypothesis is supported by the results of an earlier study by Kääb et al. (1998), which showed a net melt rate on the same order of magnitude at the same site.

In future studies the emphasis should be on both, more detailed measurements of energy balance components including the blocky layer (i.e., heat transfer by longwave radiation and turbulent fluxes due to convective and advective air circulation), and more physically based modeling of the heat source and sink terms, i.e., the representation of radiation coupled with thermal gradients in the active layer and air flow coupled to meteorological conditions.

Acknowledgements. This study was part of the German "Sensitivity of mountain Permafrost to Climate Change" Bündel project (SPCC, http://www.spcc-project.de/) funded by the German National Science Foundation (DFG, HA3475/3-1)), and the Swiss
National Science Foundation "The evolution of mountain permafrost in Switzerland” project (TEMPS, SNF, CRSII2_136279). We would like to thank the Swiss Permafrost Monitoring Network (PERMOS) for providing the measurement data. We also thank Corvatsch Bergbahn AG for transport and accommodation.

Edited by: M. Koppes

\section{References}

Arenson, L., Hoelzle, M., and Springman, S.: Borehole deformation measurements and internal structure of some rock glaciers in Switzerland, Permafrost Periglac., 13, 117-135, 2002.

Arenson, L., Hauck, C., Hilbich, C., Seward, L., Yamamoto, Y., and Springman, S.: Sub-surface heterogeneities in the MurtèlCorvatsch rock glacier, Switzerland, in: Proceedings of the 6th Canadian Permafrost Conference, 1494-1500, 2010.

Balch, E. S.: Glaciers or freezing caverns, Allen, Lane and Scott, Philadelphia, PA, 1900.

Bayard, D., Staehli, M., Parriaux, A., and Fluehler, H.: The influence of seasonally frozen soil on the snowmelt runoff at two alpine sites in southern Switzerland, J. Hydrol., 309, 66-84, 2005.

Binxiang, S., Lijun, Y., and Xuezu, X.: Onset and evaluation on winter-time natural convection cooling effectiveness of crushedrock highway embankment, Cold Reg. Sci. Technol., 48, 218 231, 2007.

Brock, B. W., Mihalcea, C., Kirkbride, M. P., Diolaiuti, G., Cutler, M. E. J., Smiraglia, C.: Meteorology and surface energy fluxes in the 2005-2007 ablation seasons at the Miage debris-covered glacier, Mont Blanc Massif, Italian Alps, J. Geophys. Res.: Atmospheres, 115, D9, doi:10.1029/2009JD013224, 2010.

Cheng, G. D., Lai, Y. M., San, Z. Z., and Jiang, F.: The "thermal semi-conductor" effect of crushed rocks, Permafrost Periglac., 18, 151-160, 2007.

Delaloye, R. and Lambiel, C.: Evidence of winter ascending air circulation throughout talus slopes and rock glaciers situated in the lower belt of alpine discontinuous permafrost (Swiss Alps), Norsk Geogr. Tidssk., 59, 194-203, 2005.

Delaloye, R., Reynard, E., Lambiel, C., Marescot, L., and Monnet, R.: Thermal anomaly in a cold scree slope (Creux du Van, Switzerland), in: Proceedings of the 8th International Conference on Permafrost, Zurich, Switzerland, edited by: Phillips, M. Springman, S. M., and Arenson, L., 175-180, Balkema Publishers, Lisse, 2003.

Devaux, J.: Radiothermic economy of fields of snow and glaciers, Science Abstr., Serias A, 36, 980-981, 1933.

Fillion, M.-H., Côté, J., and Konrad, J.-M.: Thermal radiation and conduction properties of materials ranging from sand to rock-fill, Can. Geotech. J., 48, 532-542, 2011.

Gruber, S. and Hoelzle, M.: The cooling effect of coarse blocks revisited: a modeling study of a purely conductive mechanism, in: 9th Int. Conf. on Permafrost, Institute of Northern Engineering, Fairbanks, University of Alaska, 29 June-3 July 2008, edited by: Kane, D. and Hinkel, K., 557-561, 2008.

Gustafsson, D., Stähli, M., and Jansson, P.-E.: The surface energy balance of a snow cover: comparing measurements to two differentsimulation models, Theor. Appl. Climatol., 70, 81-96, 2001. 
Haeberli, W., Huder, J., Keusen, H., Pika, J., and Röthlisberger, H.: Core drilling through rock glacier-permafrost, in: Proceedings of the Fifth International Conference on Permafrost, Vol. 2, 937942, by Senneset-Kaare, 1988.

Hanson, S. and Hoelzle, M.: The thermal regime of the active layer at the Murtèl rock glacier based on data from 2002, Permafrost Periglac., 15, 273-282, 2004.

Harris, S. A. and Pedersen, D. E.: Thermal regimes beneath coarse blocky materials, Permafrost Periglac., 9, 107-120, 1998.

Herz, T., King, L., and Gubler, H.: Microclimate within coarse debris of talus slopes in the alpine periglacial belt and its effect on permafrost, in: Proceedings of the 8th International Conference on Permafrost, Zurich, Switzerland, edited by: Phillips, M., Springman, S. M., and Arenson, L., 383-387, Balkema Publishers, Lisse, 2003.

Hoelzle, M. and Gruber, S.: Borehole and ground surface temperatures and their relationship to meteorological conditions in the Swiss Alps, in: 9th Int. Conf. on Permafrost, Institute of Northern Engineering, Fairbanks, University of Alaska, 29 June-3 July 2008, edited by: Kane, D. L. and Hinkel, K. M., 723-728, 2008.

Hoelzle, M., Vonder Mühll, D., and Haeberli, W.: Thirty years of permafrost research in the Corvatsch - Furtschellas area, Eastern Swiss Alps: A review, Norsk Geogr. Tidsskr., 56, 137-145, 2002.

IPCC: Working Group I Contribution to the IPCC Fifth Assessment Report (AR5), Climate Change 2013: The Physical Science Basis, 2013.

Jansson, P.-E. and Karlberg, L.: Coupled heat and mass transfer model for soil-plant-atmosphere systems, Royal Institute of Technology, Dept of Civil and Environmental Engineering, Stockholm, http://www.lwr.kth.se/Vara\%20Datorprogram/ CoupModel/index.htm, 2011.

Johnsson, H. and Lundin, L.-C.: Surface runoff and soil water percolation as affected by snow and soil frost, J. Hydrol., 122, 141159, 1991.

Kääb, A., Gudmundsson, G. H., and Hoelzle, M.: Surface deformation of creeping mountain permafrost. Photogrammetric investigations on rock glacier Murtèl, Swiss Alps, in: Proceedings of the 7th International Conference on Permafrost, 531-537, 1998.

Keller, F. U.: Interaktionen zwischen Schnee und Permafrost: Eine Grundlagenstudie im Oberengadin, Ph.D. thesis, Dissertation an der Abteilung Naturwissenschaften der Eidgenössisch Technischen Hochschule Zürich, 1994.

Kunii, D. and Smith, J.: Heat transfer characteristics of porous rocks, AIChE J., 6, 71-78, 1960.

Langer, M., Westermann, S., Muster, S., Piel, K., and Boike, J.: The surface energy balance of a polygonal tundra site in northern Siberia - Part 2: Winter, The Cryosphere, 5, 509-524, 2011, http://www.the-cryosphere-discuss.net/5/509/2011/.

Lundin, L. C.: Hydraulic properties in an operational model of frozen soil, J. Hydrol., 118, 289-310, 1990.

McAdams, W. H.: Heat transmission, McGraw-Hill Book Co., Inc., New York, NY, 1954.
Meder, S. E., Pennetier, O. A., Ansberry, D. M., Brunner, I. M. I. M.: Assessment of solar energy potential on existing buildings in a region, U.S. Patent 7305983 B1, December 11, 2007.

Mittaz, C., Hoelzle, M., and Haeberli, W.: First results and interpretation of energy-flux measurements over Alpine permafrost, Ann. Glaciol., 31, 275-280, 2000.

Mittaz, C., Imhof, M., Hoelzle, M., and Haeberli, W.: Snowmelt Evolution Mapping Using an Energy Balance Approach over an Alpine Terrain, Arct. Antarct. Alp. Res., 34, 274-281, 2002.

Oke, T. R.: Boundary layer climates, Routledge, 1988.

Panz, M.: Analyse von Austauschprozessen in der Auftauschicht des Blockgletschers Murtèl-Corvatsch, Oberengadin, Master's thesis, Ruhr Universität (unpublished), 2006.

Scherler, M., Hauck, C., Hoelzle, M., Stähli, M., and Völksch, I.: Meltwater infiltration into the frozen active layer at an alpine permafrost site, Permafrost Periglac., 21, 325-334, 2010.

Scherler, M., Hauck, C., Hoelzle, M., and Salzmann, N.: Modeled sensitivity of two alpine permafrost sites to RCMbased climate scenarios, J. Geophys. Res., 118, 780-794, doi:10.1002/jgrf.20069, 2013.

Schneider, S., Hoelzle, M., and Hauck, C.: Influence of surface and subsurface heterogeneity on observed borehole temperatures at a mountain permafrost site in the Upper Engadine, Swiss Alps, The Cryosphere, 6, 517-531, doi:10.5194/tc-6-517-2012, 2012.

Stähli, M., Jansson, P.-E., and Lundin, L.-C.: Preferential water flow in a frozen soil - a two-domain model approach, Hydrol. Process., 10, 1305-1316, 1996.

Stocker-Mittaz, C.: Permafrost distribution modeling based on energy balance data, Ph.D. thesis, Univ. of Zurich, Zurich, Switzerland, 2002.

Tanaka, H., Nohara, D., and Yokoi, M.: Numerical simulation of wind hole circulation and summertime ice formation at Ice Valley in Korea and Nakayama in Fukushima, Japan, JournalMeteorological Society of Japan, Series 2, 78, 611-630, 2000.

Vonder Mühll, D., Arenson, L., and Springman, S.: Two new boreholes through the Murtèl-Corvatsch rock glacier, Upper Engadin, Switzerland, in: 1st European Permafrost Conference, Abstract, p. 83, 2001.

Vonder Mühll, D., Arenson, L., and Springman, S.: Temperature conditions in two Alpine rock glaciers, in: 8th International Conference on Permafrost, Zürich, Swets \& Zeitlinger, Lisse, 11951200, 2003.

Wakonigg, H.: Unterkühlte schutthalden, Arbeiten aus dem Institut für Geographie der Karl-Franzens-Universität Graz, 33, 209 223, 1996.

Westermann, S., Lüers, J., Langer, M., Piel, K., and Boike, J.: The annual surface energy budget of a high-arctic permafrost site on Svalbard, Norway, The Cryosphere, 3, 245-263, 2009, http://www.the-cryosphere-discuss.net/3/245/2009/.

Williams, P. J. and Smith, M. W.: The frozen earth: fundamentals of geocryology, Vol. 306, Cambridge University Press, Cambridge, 1989. 